\title{
On the use of electrical resistivity method in mapping potential sources and extent of pollution of groundwater systems in Lapai Town, Niger State, Nigeria
}

\author{
Tsepav Matthew Tersoo ${ }^{1}$, Aliyu Yahaya Badeggi ${ }^{2}$, Obaje Nuhu George ${ }^{3}$ and \\ Usman Yusuf Tanko ${ }^{1}$ Ibrahim Samuel Ibbi ${ }^{4}$ \\ ${ }^{1}$ Department of Physics, Ibrahim Badamasi Babangida University, Lapai, Nigeria. \\ ${ }^{2}$ Department of Mathematics/Computer Science, Ibrahim Badamasi Babangida University, \\ Lapai, Nigeria.. \\ ${ }^{3}$ Department of Geology and Mining, Ibrahim Badamasi Babangida University, Lapai, Nigeria. \\ ${ }^{4}$ Department of Geography, Federal University, Lokoja, Nigeria \\ tsematoo@yahoo.com,tmathew39@ibbu.edu.ng +2348030939122
}

Received 23 January 2021, Revised 14 March 2021, Published 30 March 2021

\begin{abstract}
Electrical resistivity method employing the Schlumberger array was used to occupy forty four (44) vertical electrical sounding points in Lapai town with the aim of determining the depth to aquifers, aquifer thicknesses and aquifer protective capacity. The G41 Geotron resistivity meter was used in obtaining the apparent resistivity data which was processed using Interpex 1XD resistivity interpretation software. The results revealed four lithologic sections which include top lateritic soil, sandy clay, fractured basement and fresh basement. Both confined and unconfined aquifers were identified within the area, with four classes of aquifer proactive capacities as high, moderate, weak and poor. While the aquifer at VES 20 was highly protected, twenty other aquifers were moderately protected, eight others had weak protection and fifteen aquifers were poorly protected. The aquifers were generally of good thicknesses and at varying reasonable depths, making them good reservoirs of water in appreciable quantity. The average aquifer thickness was estimated to be $48.36 \mathrm{~m}$ while the average depth to aquifers was estimated to be $56.68 \mathrm{~m}$
\end{abstract}

Keyword : Aquifers, resistivity, protective capacity, Transmissivity and Conductance.

\section{Introduction}

Lapai town is the headquarters of Lapai Local Government Area of Niger State. It has an area of $3,051 \mathrm{~km}^{2}$ and a population of 110,127 at the 2006 census (Lapai, 2020). The town houses the state University, Ibrahim Badamasi Babangida University that has students' population of over 10,000, more than 1,000 employees, over $50 \%$ of whom 
reside in Lapai with their families. As a result, there is an increased influx of people to the town for business opportunities.

The town has only one seasonal stream which goes round the township up to halfway of the town's circumference. Due to uncontrolled refuse dump, the stream is highly polluted making the water from the stream unsafe for domestic and Agricultural uses. The only source of potable drinking water is through borehole drilling into underground water bodies.

Water is an essential commodity that sustains all living things. There are many sources of water including rain, well, river, stream, groundwater, etc. A large portion of the world's fresh water resides underground, stored within cracks and pores in the rock that make up the Earth's crust. Groundwater is seen as liquid flowing through shallow aquifers, but it can also include soil moisture, permafrost, immobile water in very low permeability bedrock and deep geothermal or soil formation water. In recent times, attention has shifted to the use of groundwater to meet the need for water supply, since most surface and shallow water bodies have been polluted. Groundwater is often withdrawn for agricultural, domestic and industrial use; however, the heavy concentration on its usage has become a source of concern to hydrologists. The extreme use of groundwater resources can raise concerns such as uplifting and seismic activities, ecological environment deterioration, land subsidence, vegetation degradation of livelihoods for rural poor, and food security implications. In view of the shrinking groundwater resources, it is important to develop effective techniques and methods to study the trend of groundwater storage (increase/decrease) and its recharge-discharge relationship, which can support the mitigating measures of over pumping shallow groundwater to ensure the sustainable utilization of groundwater resources (Muhammad et al., 2020).

Due to increasing urbanization, surface water and groundwater resources are prone to over contamination and more stringent treatments would be required to make them potable. Studies of physico-chemical characteristics of underground water are often required to find out whether it is fit for drinking or some other beneficial. According to Environmental protection Agency (EPA, 2018), stressors that affect groundwater condition include application of pesticides and fertilizers to the land, waste from livestock and other animals, landfills, mining operations, and unintentional releases such as chemical spills or leaks from storage tanks. Some groundwater has high levels of naturally occurring dissolved solids (salinity), or metals such as arsenic found in natural rock formations.

There are a good number of water banks in close proximity to Lapai town. Prominent among them are the Agaie/Lapai Dam at Bakajeba over Ebba River and the Gurara River, which is a tributary of the Niger River. Another river is located in Badeggi, a town about $55 \mathrm{~km}$ away from Lapai along Bida road. It is a tributary of River Kaduna. The Baro Sea Port is about $60 \mathrm{~km}$ south of Lapai. The following surface water streams and Rivers are found within and around Lapai: River Dambugi, River Makara, River Etwanyagi, River Vudi, River Shekai and River Shikugi amongst others. Given this number of rivers around Lapai, one would conclude that there should be adequate supply of potable water to Lapai 
metropolis and its environs. But what we witness is that many water projects such as Agaie/Lapai Dam, Gurara and Baro water projects are abandoned. The only public water supply agency has in Lapai Town has remained moribund over the years and the open streams are continuously being contaminated by indiscriminate refuse disposal mechanisms.

The rapid growth in the population of Lapai town occasioned by the presence of the Ibrahim Badamasi Babangida University which attracts students, workers and businessminded people in thousands every year, has led to over dependence on borehole as the only dependable source of potable water. There is therefore, the need to explore for more sources of potable water and then study the likelihood of contamination of this natural resource in Lapai town and its environs. The rapidly growing population leading to high dependence on this essential commodity coupled with illegal disposal of effluents therefore portends a serious danger on the existing sources of groundwater.

As a matter of fact, groundwater contamination is a global problem that has a significant impact on human health and ecological services (Li et al., 2021). Organic pollutants, including polycyclic aromatic hydrocarbons (PAHs) and polychlorinated biphenyls (PCBs) are common contaminants of anthropogenic origin in groundwater that could cause serious health problems. The Ololade et al., (2021), investigated PAHs and PCBs in groundwater near selected waste dumpsites located in two southwestern states in Nigeria. They found that the more water-soluble, low molecular weight-PAHs accounted for more than $61 \%$ of the total PAHs detected across all locations, but surprisingly the more highly chlorinated hexa-PCBs dominated the congener profiles. In a related work, Ambade et al., (2021) investigated the occurrence, distribution, health risk, and composition of 16 priority PAHs in drinking water from southern Jharkhand in the eastern part of India. They found that lower and middle molecular weight PAHs were dominant in groundwater from the study area, but the levels were below concentrations that could constitute a carcinogenic risk.

In their research on A Comparative Investigation of Groundwater Contamination in Typical Dumpsites and Cemetery Using Electrical Resistivity Tomography and Physicochemical Analysis of Water in Benin Metropolis, Idehen (2020), observed the implications of land utilization for burial of dead human bodies in the form of cemeteries and location of refuse dumps as having a significant potential contaminant effect in the environment and especially the groundwater component.

Electrical resistivity methods have been applied for studying variations of resistivity with depth or for lateral variations. These variations arise due to the difference in electrical properties of rocks in the lithologic units of the subsurface and fluid content. The aim of VES survey is usually to obtain true resistivity logs similar to the induction $\log$ of a well in the vicinity without actually drilling a hole. The method has remained the most inexpensive of subsurface exploration methods with a very good propensity for noble results thereby making the method very suitable for groundwater exploration.

Geophysical investigations have been carried out in different parts of the world for groundwater investigation. Oni et al., (2020) used magnetic method as a tool in groundwater investigation in a basement complex terrain. Olorunfemi et al., (1999) used 
the electrical resistivity method in investigation of geo-electric and hydro-geologic characteristics of areas in Southwest Nigeria. Ayolabi, et al., (2009) carried out groundwater investigation at Igbogbo, Lagos, using seismic refraction and electrical resistivity techniques. Osuagwu, (2009), used very low frequency electromagnetic and vertical electrical sounding techniques in delineating aquifer zones in Modeme area, Ife, Osun State. Tsepav et al., (2015) used electrical resistivity method to characterise aquifer precincts in parts of Lapai, North Central Nigeria. Oladipo et al., (2011) in their work titled "Contaminant evaluation of major drinking water sources (boreholes water) in Lapai metropolis," observed that Lapai and its environs depend solely on spring water, running stream water, private and general boreholes water for drinking and other household usages.

Tsepav and Israel (2011), conducted an investigation on some areas of Ibrahim Badamasi Babangida University, Lapai, using D. C. resistivity method. The survey was aimed at providing information on the groundwater potentials of the areas. It was discovered after analysis, that areas under study have very good groundwater potential. In another related work, Olabode et al., (2015) evaluated groundwater resources of the Middle Niger (Bida) basin. They evaluated the hydrogeological potential of the terrain. A total of about 50 boreholes located in the area were selected for study. In the final analysis, it was discovered that groundwater occurred both in confined and semi-confined conditions and that depth to water rarely exceeds $50 \mathrm{~m}$, though in some few cases the depth might be over $70 \mathrm{~m}$. On the average, they estimated well yield to vary between $1.08 \mathrm{~m}^{3} / \mathrm{hr}$ and $19 \mathrm{~m}^{3} / \mathrm{hr}$. Obiora et al., (2015) carried out electrical resistivity survey in Makurdi, Benue state capital, north-central Nigeria to evaluate aquifer protective capacity and soil corrosivity of overburden units. Using Winresist software, 3-4 geoelectric layers were obtained and the protective capacities of the study area were classified as $36.67 \%$ weak, $10 \%$ poor, $40 \%$ moderate, and $13.33 \%$ as good. The corrosivity ratings of the study area show that $10 \%$ is strongly corrosive, $23 \%$ moderately corrosive, $37 \%$ slightly corrosive, and $30 \%$ noncorrosive.

In a related study, Olajide et al., (2020) evaluated the groundwater potential and aquifer protective capacity of the overburden unit in part of Iju, Akure North, Ondo State using integrated geophysical methods involving Very Low Frequency Electromagnetic (VLF-EM) profiling and Vertical Electrical Sounding (VES). Four major traverses were established of varying length extents while forty two Vertical Electrical Soundings were also conducted with half electrode spacing varying between 1 and $100 \mathrm{~m}$ and interpretation was done using the partial curve matching techniques and computer aided iteration. Five subsurface geological units were identified consisting of the top soil, lateritic, weathered, partly weathered and fresh basement layers consecutively. The aquifer protective capacity of the study area shows that close to $70 \%$ of the study area fell within the zones of low groundwater potential, $25 \%$ falls within medium potential zones while only $5 \%$ made up the high potential zones while $75 \%$ of the study area constituted the weak to poor protective capacity zones.

The data used in this study was obtained from Lapai town within $5 \mathrm{~km}$ radius. Thus the result of this work may not be applicable to locations other than this, except where similar 
conditions prevail. The scope of the study will cover geophysical mapping of good aquifers, depth to aquifer measurements and determination of aquifer protective capacity.

\section{Geology of the study area}

About ninety per cent ( $90 \%$ ) of Lapai is underlain by rocks of the basement complex and about ten per cent $(10 \%)$ by sedimentary rocks (Obaje et al., 2020). The basement complex rocks occur to the north, south and east of Lapai while sedimentary rocks cover the areas to the West with contact to the basement at the stream valley by the Water Board on the road to Agaie (Fig. 1). These different rock types determine the water table levels, the aquifer systems and the water budget. These variables become more diversified depending on the component of the basement complex and the sedimentary formation that make up the bedrock under study. The bedrock geology of Lapai can further be discussed within the context of the regional geology of Nigeria made up of the Basement Complex, Younger Granites and Sedimentary Basins (Fig. 2).

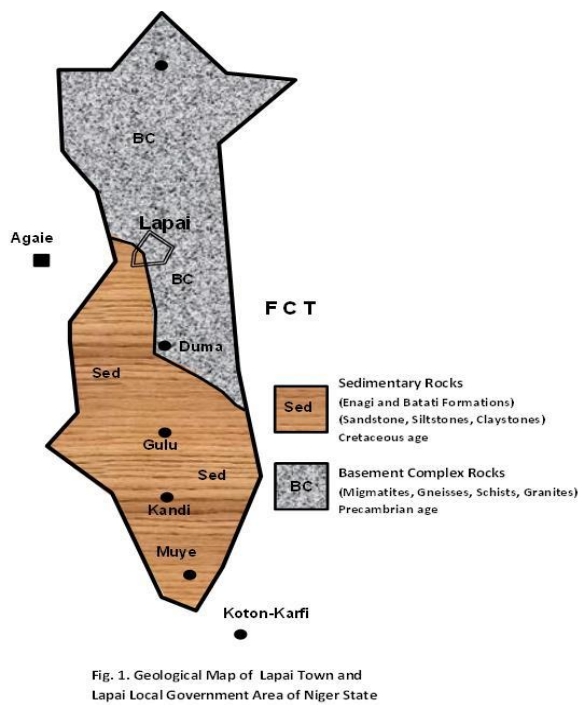

Figure 1. Geological Map of Town and Lapai Local Government area

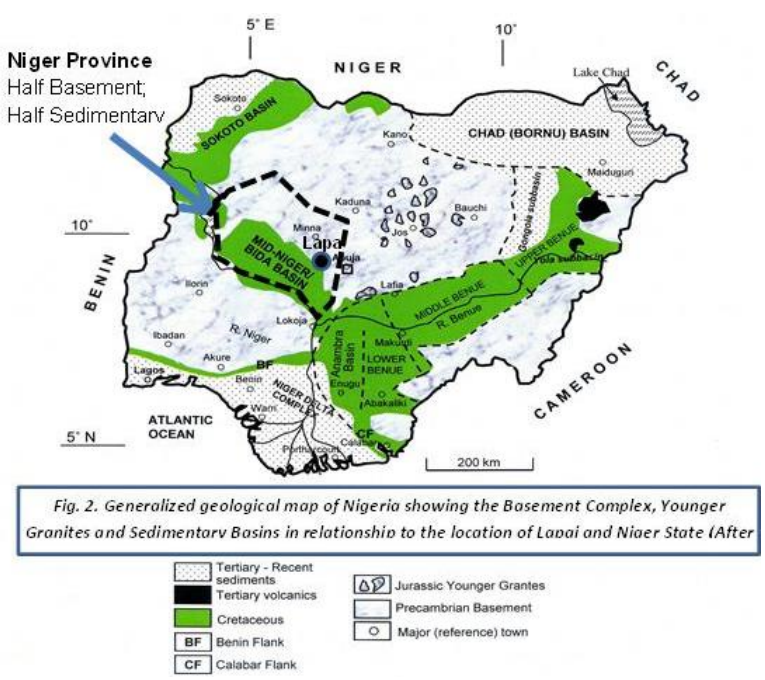

Figure 2. Generalized geological map of Nigeria

\subsection{The Basement Complex Rocks}

Within the basement complex of Nigeria three major petro-lithological units are distinguishable, namely: Migmatite - Gneisses, Schists, and Older Granites (differentiating them from the Younger Granites concentrated around Jos).

The Migmatite - Gneiss Complex is generally considered as the basement complex sensu stricto and it is the most widespread of the component units in the Nigerian basement It has a heterogeneous assemblage comprising migmatites, gneises, and a series of basic and ultra-basic metamorphosed rocks (Rahaman et al., 2019) and it is the most widespread of the component units in the Nigerian basement Obaje et al., (2019). It has a heterogeneous assemblage comprising migmatites, gneises, and a series of basic and ultra-basic metamorphosed rocks. They generally occur intricately associated with the Older Granites intruding into them and in some places along with schist belts, but 
chronologically the Migmatite-Gneiss complexes are oldest (older than Schist Belts older than Older Granites). In Lapai area, Migmatite-Gneisses occur to the east and are readily mappable on the road that passes through Gulu Junction (Mararaba) though Kudna to Lambata. Schistose rocks are also very abundant on the same axis. Older Granites dominate the bedrock cover from Lapai central to the north on Lapai - Paiko road.

\subsection{Sedimentary Rocks}

In Lapai, sedimentary rocks comprising the Bida Sandstone and the Enagi Formation (made up mainly of sandstones, siltstones and claystones) form the bedrock to the west beginning from the stream channel at the Lapai Water Board office. As stated earlier, these rock types (sedimentary) make up only about $10 \%$ of the total areal rock cover of Lapai. The sedimentary rocks belong to the larger sedimentary sequences that form the Bida Basin. The Bida Basin itself is a NW-SE trending intracratonic structure extending from slightly south of Kontagora in Niger State in the north to the area slightly beyond Lokoja (Kogi State) in the south. The formations deposited in the Bida Basin comprise the Bida Sandstone at the base, followed successively upward by the Sakpe, Enagi and Batati Formations in the Northern/Central Bida Basin while the Lokoja, Patti and Agbaja Formations constitute lateral equivalents in the Southern Bida Basin (Obaje et al., 2020).

\section{Materials and Methods}

\subsection{Materials}

The materials used for the work were G41 Resistivity Meter, non-polarizable electrodes, current and potential cable reels, hammers, measuring tapes, GPS device, recording materials and Interpex 1XD Resistivity interpretation software.

\subsection{Theory of Electrical Resistivity}

These are based on Ohm's law which holds for simple circuits as well as earth materials through which current flows. When measurements are made over a heterogeneous earth, it is apparent resistivity $\rho a$ that is measured. These apparent resistivity values from field observations at various locations, and with various electrode configurations, are used to estimate the true resistivities of the several earth materials present at a site and to locate their boundaries spatially below the surface of the site. The apparent resistivity is expressed as:

$$
\rho_{a}=\frac{K \Delta \mathrm{V}}{\mathrm{I}}
$$

where $\Delta \mathrm{V}$ and I are voltage drop and current respectively and

$$
K=2 \pi\left(\frac{1}{r_{1}}-\frac{1}{r_{2}}-\frac{1}{r_{3}}-\frac{1}{r_{4}}\right)^{-1}
$$

is the geometric factor which depends on the electrode spacing.

An electrode array with constant spacing is used to investigate lateral changes in apparent resistivity reflecting lateral geologic variability or localized anomalous features while the electrode spacing is varied if the changes in resistivity with depth are to be investigated (Tsepav et al., 2015). The types of electrode arrays that are most commonly 
used are Schlumberger and Wenner. In each case, direct current is passed into the earth at $A$ and received at $B$. The potential generated in the earth as a result of this current is measured between the potential electrodes $M$ and $N$ as shown in Figure 3.

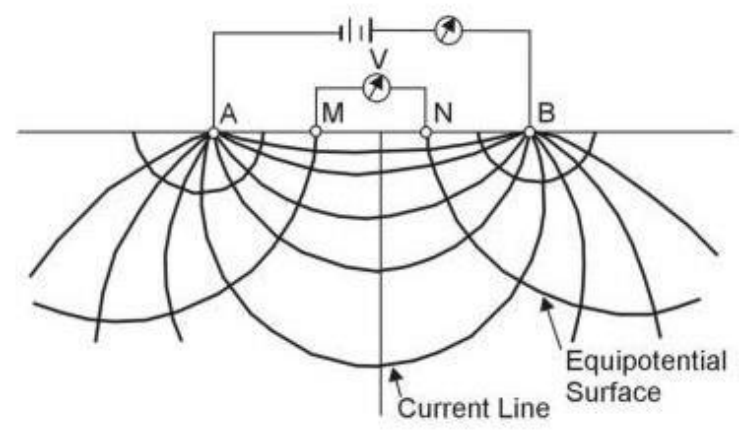

Figure 3. Electrode configuration

\subsection{Aquifer Protective Capacity Evaluation}

The ability of an earth medium to retard and filter percolating fluid is the measure of its protective capacity (Olorunfemi et al., 1999). The protective capacity of an overburden exerted by retardation and filtration of percolating pollutants is directly proportional to its thickness and inversely proportional to its hydraulic conductivity. As such, clayey material content is generally characterized by low permeability, low resistivity, low hydraulic conductivity and longitudinal unit conductance values. Hence the protective capacity can be considered as being proportional to the longitudinal conductance (S). Therefore, the higher the overburden longitudinal conductance of an area, the higher its protective capacity.

If we have $n-1$ layers overlying a semi-infinite substratum of resistivity $\rho_{\mathrm{n}}$, the Longitudinal Conductance S is obtained according to Bello et al., (2019) as:

$$
S_{i}=\sum_{i=0}^{n} \frac{h_{i}}{\rho_{i}} \text { (Siemens) }
$$

where $\rho_{i}$ and $h_{i}$ are the layer resistivity and thickness of the $i^{\text {th }}$ layer respectively.

The protective capacity $\left(P_{c}\right)$ of an overburden layer is proportional to its longitudinal conductance S, so that:

$$
P_{c}=S
$$

According to Bello et al., (2019) when the longitudinal conductance value is greater than 0.7 mhos, the layers are adjudged zones of good protective capacity. The portion where the conductance value ranges between 0.2 and 0.69 mhos is classified as zones of moderate protective capacity. The zones which have conductance value ranging from 0.1 and 0.19 mhos are classified as zones of weak protective capacity and where it is less than 0.1 mhos the areas are considered as having poor protective capacity.

The Dar Zarouk parameter for transverse resistance (R) is expressed by Bello et al., (2019) as:

$$
R_{i}=\sum_{i=1}^{n} h_{i} \cdot \rho_{i}\left(\text { ohm. } m^{2}\right)
$$

where $p_{i}$ is the layer resistivity and $h_{i}$ is the thickness of the ith layer.

Transverse resistance is numerically equal to the transmissivity, T. If the transverse resistance values are $>400 \Omega \mathrm{m}^{2}$ and correspond to zones where the thicknesses and 
resistivities of the aquifer are large, the aquifer materials are highly permeable to fluid movement within the aquifer, which may possibly enhance the migration and circulation of contaminants in the groundwater aquifer (Bello et al., 2019).

\subsection{Field Procedure}

The preliminary field techniques involved clearing of profiles, measurements and pegging at prospective electrode points. The G41 Geotron Resistivity Meter was used for data collection, while a global positioning system (GPS) device model 60Cx was used to obtain the coordinates of each VES point. Direct current was introduced into the ground through a pair of steel, non-polarizable electrodes driven into the ground. Two potential electrodes closely spaced and symmetrical about the sounding point were sandwiched by two current electrodes.

Measurements of the apparent resistivity values were then read off from the equipment at each potential and current electrode spacing, at the lowest standard deviation. To increase the depth of investigation, the current electrode separation was increased while the potential separation remained constant. The potential electrodes were however changed whenever a loss in sensitivity was noticed and measurements repeated for the same current spacing.

With the use of Schlumberger electrode spacing, forty four (44) VES stations were occupied and the apparent resistivity data so obtained were plotted against half electrode separation on a logarithmic scale and interpreted quantitatively using the interpex $1 \mathrm{xD}$ sounding interpretation software which provides an automatic means of analyzing and determining models.

\section{Results and Discussion}

The quantitative treatment of the vertical electrical soundings provided geoelectric information characterized by the values of resistivity and thickness. These geoelectric parameters defined the geoelectric model.

VES 1 - 4 were obtained in Magaji area of Lapai while VES 5- 8 and $9-12$ were respectively obtained from Galadima and Kure areas. VES 13 - 16 were situated in Mararaba area with VES points $17-20$ located in Lapai Market while IBB University contributed VES points $21-44$.

The raw resistivity values measured at various VES points within the study area using Schlumberger array were plotted against half electrode spacing $(\mathrm{AB} / 2)$ using Interpex 1XD software to obtain the resistivities of the various subsurface layers together with their thicknesses. This information was then used to compute the longitudinal conductance and transmissivity values for each layer using equations (8) and (9) respectively, from where aquifer protectivity was inferred.

Figures $4(a-f)$ show the results of the plot along with depth logs while Table 1 shows the number of layers, resistivity of each layer, layer thickness, depth to top of each layer, longitudinal conductance, transverse resistance and lithology of the layers. Four basic lithologic units comprising the top lateritic soil; sandy clay; fractured basement and the basement rock were delineated. Table 2 shows the protective capacity of aquifers at each 
VES point, based on the total longitudinal conductance of the overburden, and using the rating by Bello et al., (2019).
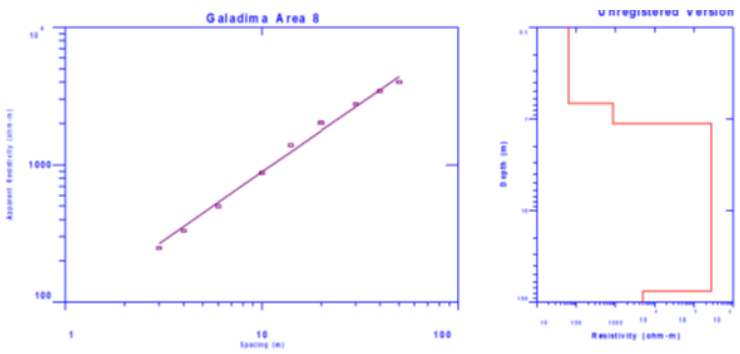

(a) Apparent Resistivity vs $\mathrm{AB} / 2$ with depth log for VES 1
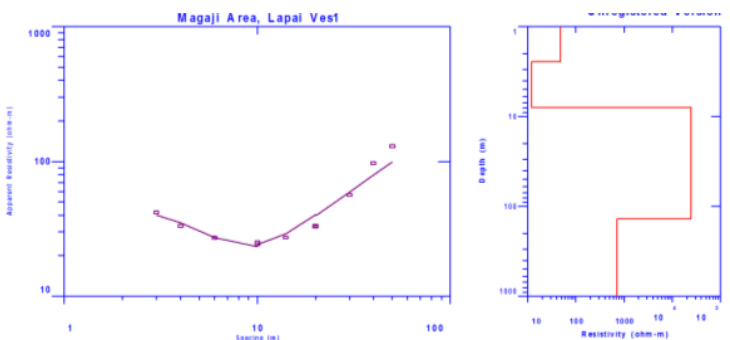

(b) Apparent Resistivity vs $\mathrm{AB} / 2$ with depth $\log$ for VES 9
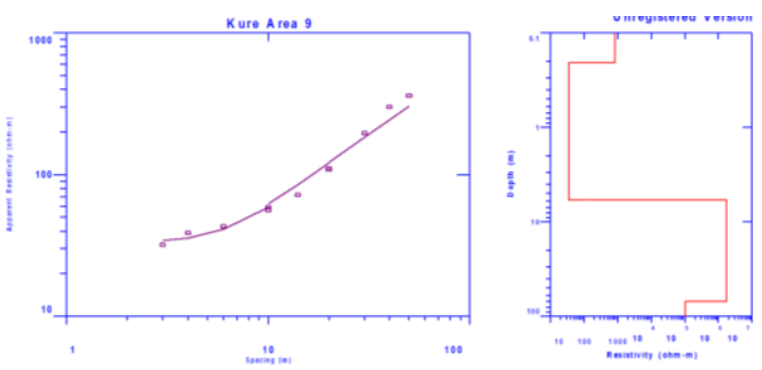

(c) Apparent Resistivity vs $\mathrm{AB} / 2$ with depth $\log$ for VES 8
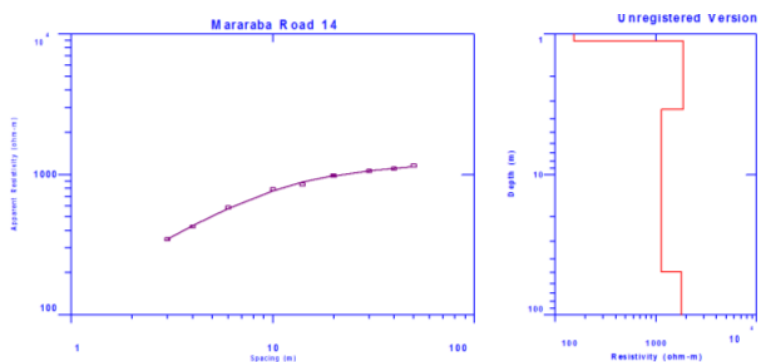

(d) Apparent Resistivity vs AB/2 with depth log for VES 14
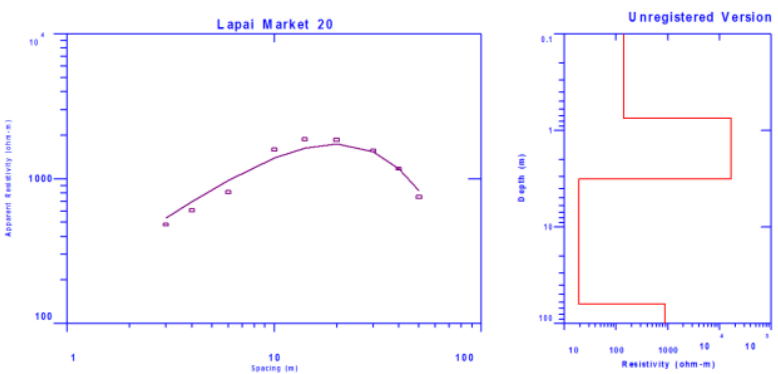

(e) Apparent Resistivity vs $\mathrm{AB} / 2$ with depth $\log$ for VES 20
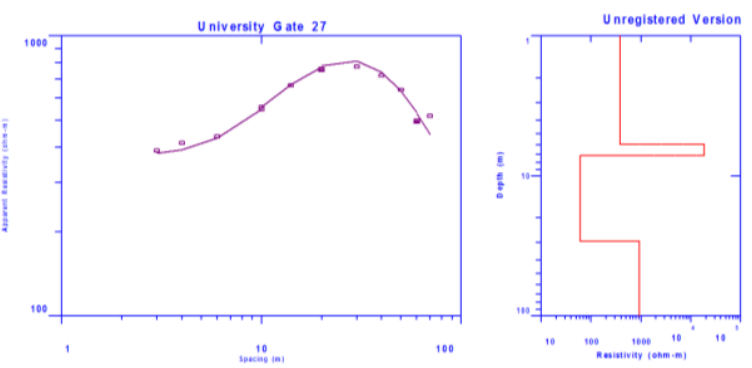

(e) Apparent Resistivity vs AB/2 with depth log for VES 27

Figure 4 (a - f). Graphs of Apparent Resistivity vs AB/2 with depth logs for selected VES points

Table 1. layered earth models for the ves stations

\begin{tabular}{|c|c|c|c|c|c|c|c|c|}
\hline $\begin{array}{l}\text { VES } \\
\text { Point }\end{array}$ & Coordinates & Layer & $\begin{array}{l}\text { Resistivity } \\
(\Omega \mathrm{m})\end{array}$ & $\begin{array}{l}\text { Thickness } \\
\text { (m) }\end{array}$ & $\begin{array}{l}\text { Depth } \\
\text { (m) }\end{array}$ & $\begin{array}{l}\text { Long. Cond. } \\
\text { (Siemens) }\end{array}$ & $\begin{array}{l}\text { Trans. } \\
(\text { ohm.m²) }\end{array}$ & Lithology \\
\hline \multirow[t]{6}{*}{1} & $09^{\circ} 02.794 \mathrm{~N}$ & 1 & 47.93 & 2.46 & 2.46 & 0.0513 & 117.9 & Top lateritic \\
\hline & $006^{\circ} 34.137 \mathrm{E}$ & 2 & 12.19 & 5.46 & 7.92 & 0.448 & 66.69 & soil \\
\hline & & 3 & 24148.4 & 128.5 & 136.4 & 0.00532 & $3.105 \mathrm{E}+06$ & Sandy clay \\
\hline & & 4 & 713.0 & $\infty$ & $\infty$ & & & Fractured \\
\hline & & & & & & & & basement \\
\hline & & & & & & & & Fresh \\
\hline \multirow{8}{*}{2} & $09^{\circ} 02798 \mathrm{~N}$ & 1 & 1836 & 0761 & 0761 & 00414 & 1397 & Ton lateritic \\
\hline & OQ & 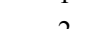 & 1505 & 0212 & 0.74 & $654 \mathrm{E} 04$ & 0010 & \\
\hline & $00634.140 \mathrm{E}$ & 2 & 459.5 & 0.213 & 0.974 & $4.654 \mathrm{E}-04$ & 98.10 & soil \\
\hline & & 3 & 73289.4 & 86.95 & 87.92 & 0.00119 & $6.373 \mathrm{E}+06$ & Sandy clay \\
\hline & & 4 & 1285.9 & $\infty$ & $\infty$ & & & Fractured \\
\hline & & & & & & & & basement \\
\hline & & & & & & & & Fresh \\
\hline & & & & & & & & basement \\
\hline
\end{tabular}




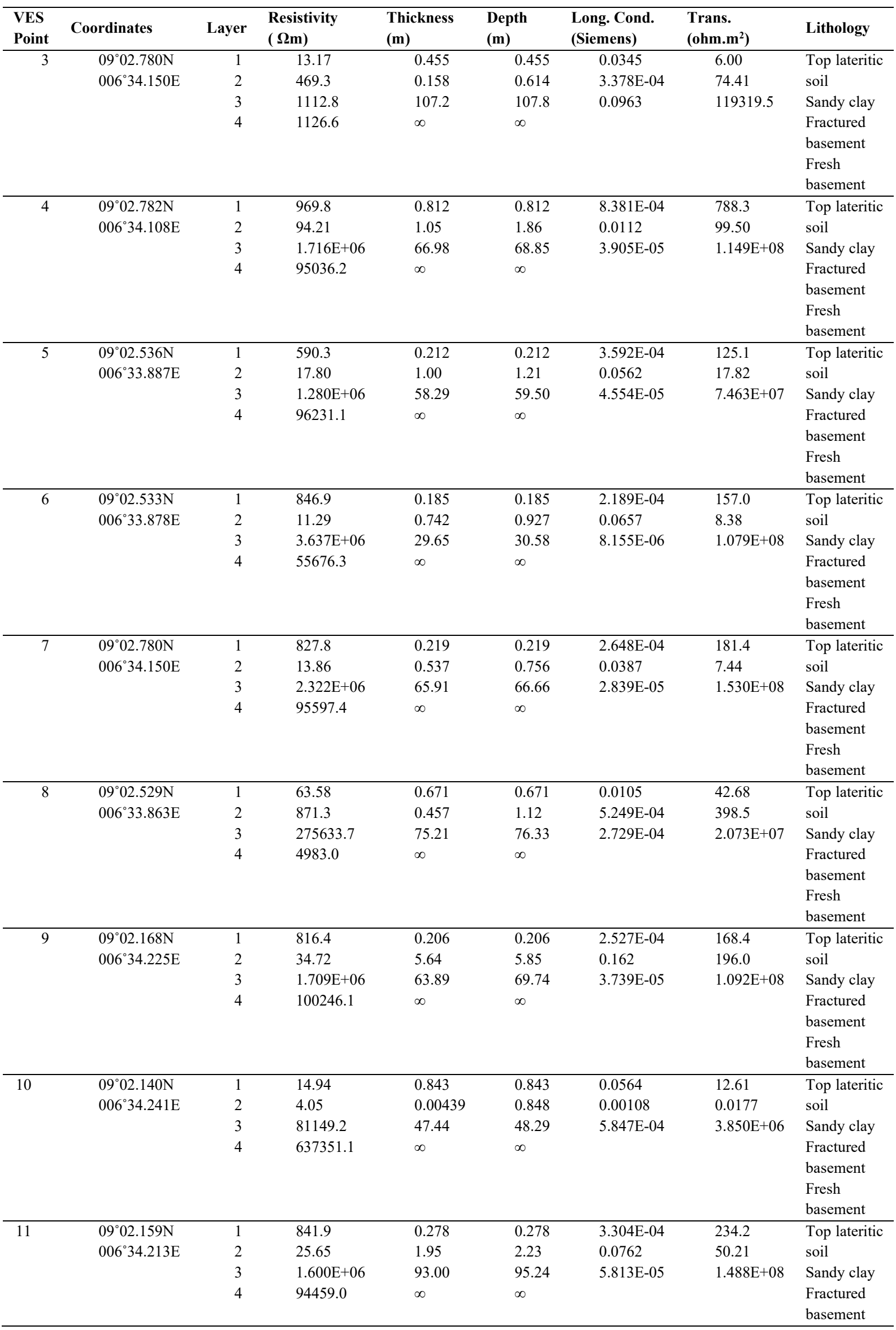




\begin{tabular}{|c|c|c|c|c|c|c|c|c|}
\hline $\begin{array}{l}\text { VES } \\
\text { Point }\end{array}$ & Coordinates & Layer & $\begin{array}{l}\text { Resistivity } \\
\text { ( } \Omega \mathrm{m})\end{array}$ & $\begin{array}{l}\text { Thickness } \\
\text { (m) }\end{array}$ & $\begin{array}{l}\text { Depth } \\
\text { (m) }\end{array}$ & $\begin{array}{l}\text { Long. Cond. } \\
\text { (Siemens) }\end{array}$ & $\begin{array}{l}\text { Trans. } \\
\left(\text { ohm.m }{ }^{2}\right)\end{array}$ & Lithology \\
\hline & & & & & & & & $\begin{array}{l}\text { Fresh } \\
\text { basement }\end{array}$ \\
\hline \multirow[t]{4}{*}{12} & $09^{\circ} 02.168 \mathrm{~N}$ & 1 & 61.72 & 1.16 & 1.16 & 0.0188 & 71.72 & Top lateritic \\
\hline & $006^{\circ} 34.225 \mathrm{E}$ & 2 & 873.2 & 1.06 & 2.22 & 0.00122 & 929.6 & soil \\
\hline & & 3 & 161044.4 & 106.2 & 108.4 & $6.597 \mathrm{E}-04$ & $1.711 \mathrm{E}+07$ & Sandy clay \\
\hline & & 4 & 3931.3 & $\infty$ & $\infty$ & & & $\begin{array}{l}\text { Fractured } \\
\text { basement } \\
\text { Fresh } \\
\text { basement }\end{array}$ \\
\hline \multirow[t]{4}{*}{13} & $09^{\circ} 02.442 \mathrm{~N}$ & 1 & 809.2 & 0.196 & 0.196 & $2.432 \mathrm{E}-04$ & 159.2 & Top lateritic \\
\hline & $006^{\circ} 34.479 \mathrm{E}$ & 2 & 8.94 & 0.938 & 1.13 & 0.104 & 8.39 & soil \\
\hline & & 3 & $1.735 \mathrm{E}+06$ & 86.36 & 87.49 & 4.979E-05 & $1.498 \mathrm{E}+08$ & Sandy clay \\
\hline & & 4 & 11512.7 & $\infty$ & $\infty$ & & & $\begin{array}{l}\text { Fractured } \\
\text { basement } \\
\text { Fresh } \\
\text { basement }\end{array}$ \\
\hline \multirow[t]{4}{*}{14} & $09^{\circ} 02.456 \mathrm{~N}$ & 1 & 154.3 & 1.11 & 1.11 & 0.00723 & 172.2 & Top lateritic \\
\hline & $006^{\circ} 34.476 \mathrm{E}$ & 2 & 1865.8 & 2.31 & 3.43 & 0.00124 & 4322.6 & soil \\
\hline & & 3 & 1136.6 & 45.39 & 49.39 & 0.0404 & 52240.4 & Sandy clay \\
\hline & & 4 & 1804.5 & $\infty$ & $\infty$ & & & $\begin{array}{l}\text { Fractured } \\
\text { basement } \\
\text { Fresh } \\
\text { basement }\end{array}$ \\
\hline \multirow[t]{4}{*}{15} & $09^{\circ} 02.455 \mathrm{~N}$ & 1 & 30.62 & 1.19 & 1.19 & 0.0390 & 36.58 & Top lateritic \\
\hline & $006^{\circ} 34.459 \mathrm{E}$ & 2 & 48.33 & 0.690 & 1.88 & 0.0142 & 33.39 & soil \\
\hline & & 3 & 52227.8 & 89.42 & 91.31 & 0.00171 & $4.671 \mathrm{E}+06$ & Sandy clay \\
\hline & & 4 & 1213.4 & $\infty$ & $\infty$ & & & $\begin{array}{l}\text { Fractured } \\
\text { basement } \\
\text { Fresh } \\
\text { basement }\end{array}$ \\
\hline \multirow[t]{4}{*}{16} & $09^{\circ} 02.424 \mathrm{~N}$ & 1 & 75.30 & 0.461 & 0.461 & 0.00613 & 34.75 & Top lateritic \\
\hline & $006^{\circ} 34.425 \mathrm{E}$ & 2 & 1180.1 & 77.86 & 78.32 & 0.0659 & 91894.9 & soil \\
\hline & & 3 & $1.655 \mathrm{E}+06$ & 5.32 & 83.65 & $3.219 \mathrm{E}-06$ & $8.820 \mathrm{E}+06$ & Sandy clay \\
\hline & & 4 & 77044.8 & $\infty$ & $\infty$ & & & $\begin{array}{l}\text { Fractured } \\
\text { basement } \\
\text { Fresh } \\
\text { basement }\end{array}$ \\
\hline \multirow[t]{4}{*}{17} & $09^{\circ} 02.719 \mathrm{~N}$ & 1 & 10.24 & 0.679 & 0.679 & 0.0663 & 6.96 & Top lateritic \\
\hline & $006^{\circ} 34.426 \mathrm{E}$ & 2 & 361.3 & 0.647 & 1.32 & 0.00179 & 234.0 & soil \\
\hline & & 3 & 987414.9 & 73.07 & 74.39 & $7.400 \mathrm{E}-05$ & $7.215 \mathrm{E}+07$ & Sandy clay \\
\hline & & 4 & 15757.9 & $\infty$ & $\infty$ & & & $\begin{array}{l}\text { Fractured } \\
\text { basement } \\
\text { Fresh } \\
\text { basement }\end{array}$ \\
\hline \multirow[t]{4}{*}{18} & $09^{\circ} 02.714 \mathrm{~N}$ & 1 & 12.43 & 1.36 & 1.36 & 0.109 & 16.93 & Top lateritic \\
\hline & $006^{\circ} 34.456 \mathrm{E}$ & 2 & 10.22 & $5.486 \mathrm{E}-$ & 1.36 & $5.363 \mathrm{E}-05$ & 0.00561 & soil \\
\hline & & 3 & 20737.5 & 04 & 41.11 & 0.00192 & 824290.5 & Sandy clay \\
\hline & & 4 & 5595.5 & $\begin{array}{l}39.74 \\
\infty\end{array}$ & $\infty$ & & & $\begin{array}{l}\text { Fractured } \\
\text { basement } \\
\text { Fresh } \\
\text { basement }\end{array}$ \\
\hline \multirow[t]{4}{*}{19} & $09^{\circ} 02.724 \mathrm{~N}$ & 1 & 161.1 & 0.942 & 0.942 & 0.00585 & 151.8 & Top lateritic \\
\hline & $006^{\circ} 34.462 \mathrm{E}$ & 2 & 19.59 & 1.60 & 2.54 & 0.0817 & 31.38 & soil \\
\hline & & 3 & 38510.6 & 90.47 & 93.01 & 0.00235 & $3.484 \mathrm{E}+06$ & Sandy clay \\
\hline & & 4 & 1841.2 & $\infty$ & $\infty$ & & & $\begin{array}{l}\text { Fractured } \\
\text { basement } \\
\text { Fresh } \\
\text { basement }\end{array}$ \\
\hline \multirow[t]{4}{*}{20} & $09^{\circ} 02.728 \mathrm{~N}$ & 1 & 142.1 & 0.751 & 0.751 & 0.00529 & 106.7 & Top lateritic \\
\hline & $006^{\circ} 34.471 \mathrm{E}$ & 2 & 16621.6 & 2.44 & 3.19 & $1.470 \mathrm{E}-04$ & 40623.3 & soil \\
\hline & & 3 & 19.02 & 59.27 & 62.47 & 3.11 & 1127.9 & Sandy clay \\
\hline & & 4 & 891.4 & $\infty$ & $\infty$ & & & \\
\hline
\end{tabular}




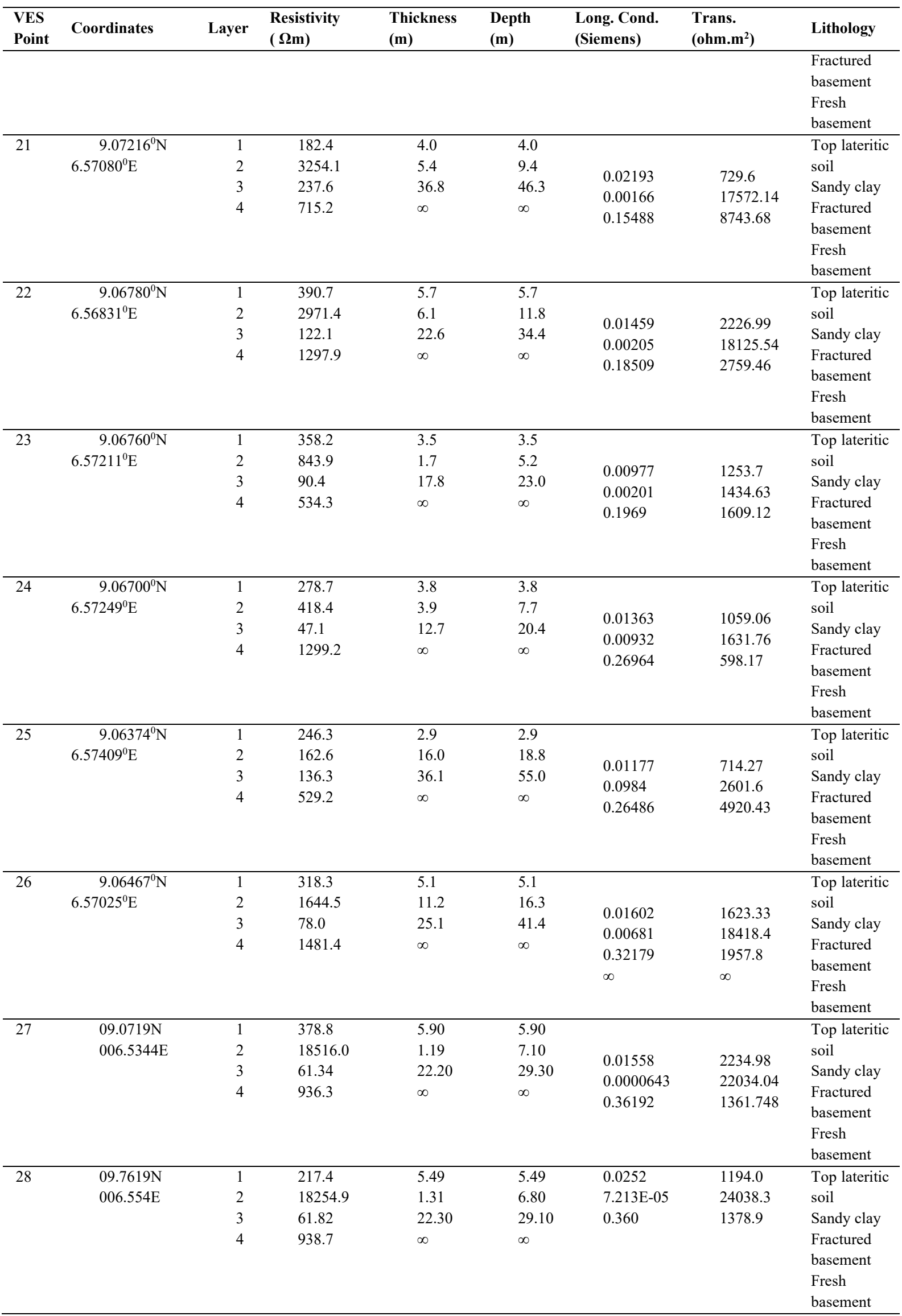




\begin{tabular}{|c|c|c|c|c|c|c|c|c|}
\hline $\begin{array}{l}\text { VES } \\
\text { Point }\end{array}$ & Coordinates & Layer & $\begin{array}{l}\text { Resistivity } \\
\text { ( } \Omega \mathrm{m})\end{array}$ & $\begin{array}{l}\text { Thickness } \\
\text { (m) }\end{array}$ & $\begin{array}{l}\text { Depth } \\
\text { (m) }\end{array}$ & $\begin{array}{l}\text { Long. Cond. } \\
\text { (Siemens) }\end{array}$ & $\begin{array}{l}\text { Trans. } \\
\left(\text { ohm.m }{ }^{2}\right)\end{array}$ & Lithology \\
\hline \multirow[t]{6}{*}{29} & $09.7535 \mathrm{~N}$ & 1 & 475.2 & 1.43 & 1.43 & 0.00301 & 680.8 & Top lateritic \\
\hline & $006.5532 \mathrm{E}$ & 2 & 301.8 & 7.76 & 9.19 & 0.0257 & 2343.8 & soil \\
\hline & & 3 & 124.3 & 41.45 & 50.65 & 0.333 & 5155.7 & Sandy clay \\
\hline & & 4 & 298.8 & $\infty$ & $\infty$ & & & Fractured \\
\hline & & & & & & & & basement \\
\hline & & & & & & & & $\begin{array}{l}\text { Fresh } \\
\text { basement }\end{array}$ \\
\hline \multirow[t]{7}{*}{30} & $09^{\circ} 02^{\prime} 57.3 \mathrm{~N}$ & 1 & 83.119 & 17.4 & 17.4 & & & Top lateritic \\
\hline & $006^{\circ} 35^{\prime} 59.9 \mathrm{E}$ & 2 & 24932.1 & 34.7 & 52.1 & & & soil \\
\hline & & 3 & 765.80 & 40.0 & 92.1 & 0.209338 & 1446.271 & Sandy clay \\
\hline & & 4 & 1060.8 & $\infty$ & $\infty$ & 0.001392 & 865143.9 & Fractured \\
\hline & & & & & & & & basement \\
\hline & & & & & & & & Fresh \\
\hline & & & & & & & & basement \\
\hline \multirow[t]{7}{*}{31} & $09^{\circ} 02^{\prime} 55.6 \mathrm{~N}$ & 1 & 25.126 & 2.00 & 2.00 & 0.079599 & 50.252 & Top lateritic \\
\hline & $006^{\circ} 35^{\prime} 56.3 \mathrm{E}$ & 2 & 79.901 & 4.40 & 6.40 & 0.055068 & 351.564 & soil \\
\hline & & 3 & 137.68 & 10.0 & 16.4 & 0.072632 & 1376.8 & Sandy clay \\
\hline & & 4 & 998.06 & $\infty$ & $\infty$ & & & Fractured \\
\hline & & & & & & & & basement \\
\hline & & & & & & & & Fresh \\
\hline & & & & & & & & basement \\
\hline \multirow[t]{7}{*}{32} & $09^{\circ} 02^{\prime} 53.6 \mathrm{~N}$ & 1 & 28.112 & 6.03 & 6.03 & & & Top lateritic \\
\hline & $006^{\circ} 35^{\prime} 52.9 \mathrm{E}$ & 2 & 711.09 & 1.55 & 7.59 & & & soil \\
\hline & & 3 & 1579.7 & 30.0 & 37.59 & $\begin{array}{l}0.213432 \\
0.010688\end{array}$ & $\begin{array}{l}108.0 / 2 \\
5404284\end{array}$ & Sandy clay \\
\hline & & 4 & 0.11779 & $\infty$ & $\infty$ & 0.010000 & $\begin{array}{l}3404.204 \\
5938092\end{array}$ & Fractured \\
\hline & & & & & & & & basement \\
\hline & & & & & & & & Fresh \\
\hline & & & & & & & & basement \\
\hline \multirow[t]{7}{*}{33} & $09^{\circ} 02^{\prime} 54.4 \mathrm{~N}$ & 1 & 96.765 & 2.47 & 2.47 & & & Top lateritic \\
\hline & $006^{\circ} 36^{\prime} 01.2 \mathrm{E}$ & 2 & 13.244 & 2.45 & 4.92 & & & soil \\
\hline & & 3 & 102.34 & 0.14 & 4.92 & $\begin{array}{l}0.025034 \\
0.188822\end{array}$ & 241.925 & Sandy clay \\
\hline & & 4 & 0.23839 & $\infty$ & $\infty$ & $\begin{array}{l}0.188822 \\
0.001368\end{array}$ & $\begin{array}{l}33.1 \\
14.3276\end{array}$ & Fractured \\
\hline & & & & & & & & basement \\
\hline & & & & & & & & Fresh \\
\hline & & & & & & & & ment \\
\hline \multirow[t]{7}{*}{34} & $09^{\circ} 02^{\prime} 43.7 \mathrm{~N}$ & 1 & 195.95 & 3.38 & 3.38 & & & Top lateritic \\
\hline & $006^{\circ} 36^{\prime} 01.6 \mathrm{E}$ & 2 & 216.59 & 5.87 & 9.25 & & & soil \\
\hline & & 3 & 483.88 & 60.0 & 69.3 & $0.01 / 249$ & $\begin{array}{l}002.511 \\
1271282\end{array}$ & Sandy clay \\
\hline & & 4 & 1221.4 & $\infty$ & $\infty$ & $0.02 / 102$ & $12 / 1.383$ & Fractured \\
\hline & & & & & & & & basement \\
\hline & & & & & & & & Fresh \\
\hline & & & & & & & & basement \\
\hline \multirow[t]{7}{*}{35} & $09^{\circ} 02^{\prime} 50.5 \mathrm{~N}$ & 1 & 13.780 & 0.77 & 0.77 & & & Top lateritic \\
\hline & $006^{\circ} 35^{\prime} 53.6 \mathrm{E}$ & 2 & 214.96 & 0.67 & 0.84 & & & soil \\
\hline & & 3 & 1033.7 & 10.0 & 10.8 & 0.058055 & $\begin{array}{l}11.024 \\
150472\end{array}$ & Sandy clay \\
\hline & & 4 & 129.83 & $\infty$ & $\infty$ & 0.003256 & $150.4 / 2$ & Fractured \\
\hline & & & & & & & & basement \\
\hline & & & & & & & & Fresh \\
\hline & & & & & & & & basement \\
\hline \multirow[t]{7}{*}{36} & $09^{\circ} 02^{\prime} 59.8 \mathrm{~N}$ & 1 & 44.045 & 2.27 & 2.27 & & & Top lateritic \\
\hline & $006^{\circ} 36^{\prime} 04.6 \mathrm{E}$ & 2 & 107.93 & 3.05 & 5.32 & & & soil \\
\hline & & 3 & 275.85 & 46.0 & 51.3 & $\begin{array}{l}0.031550 \\
0.028267\end{array}$ & $\begin{array}{l}99.90215 \\
329095\end{array}$ & Sandy clay \\
\hline & & 4 & 525.00 & $\infty$ & $\infty$ & $\begin{array}{l}0.028267 \\
0.166757\end{array}$ & $\begin{array}{l}329.095 \\
126891\end{array}$ & Fractured \\
\hline & & & & & & & & basement \\
\hline & & & & & & & & Fresh \\
\hline & & & & & & & & basement \\
\hline \multirow[t]{4}{*}{37} & $09^{\circ} 02^{\prime} 47.3 \mathrm{~N}$ & 1 & 175.33 & 0.82 & 0.82 & & & Top lateritic \\
\hline & $006^{\circ} 35^{\prime} 59.1 \mathrm{E}$ & 2 & 22.272 & 0.74 & 1.57 & $0.0046 / 1$ & $\begin{array}{l}143.1 / 06 \\
164708\end{array}$ & soil \\
\hline & & 3 & 307.80 & 54.0 & 55.6 & $\begin{array}{l}0.033229 \\
0.175430\end{array}$ & $\begin{array}{l}10.4 / 98 \\
166212\end{array}$ & Sandy clay \\
\hline & & 4 & 0.1255 & & & & 10021.2 & $\begin{array}{l}\text { Fractured } \\
\text { basement }\end{array}$ \\
\hline
\end{tabular}




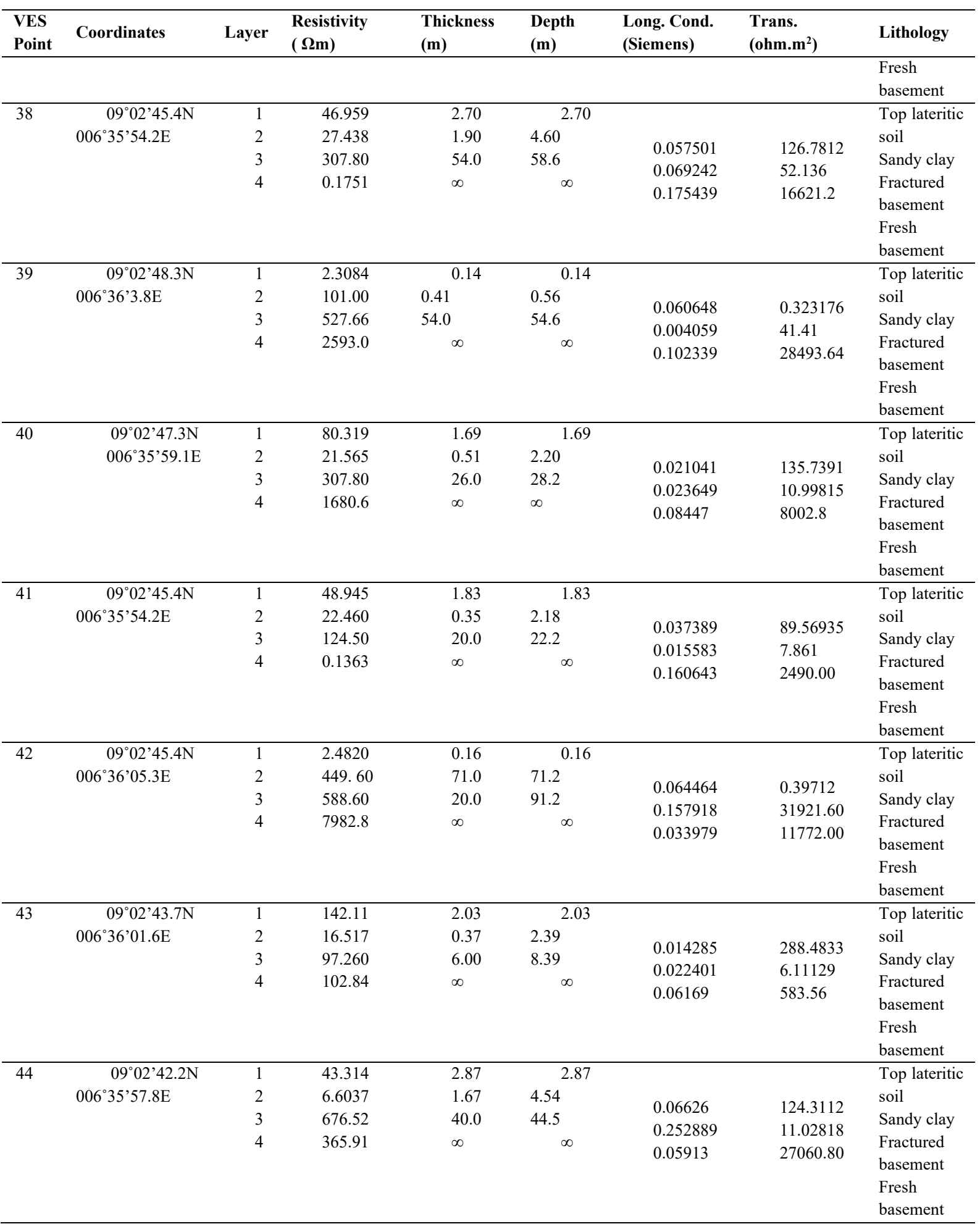

An examination of the interpreted data has revealed both confined and unconfined aquifers within the study area. Three VES points displayed some irregular patterns by having very low resistivity values for the basement rock compared to the fractured basement. These irregularities were observed at VES points 33, 38 and 41 (Table 1 refers). These low resistivities could be attributed to the presence of high conductive material in the basement which could be rich in ironstones. 
Whereas the aquifer formations at VES points 20, 21, 22, 23, 24, 25, 26, 27, 29, 30, $31,34,36,39,40,42$ and 43 were identified as unconfined aquifers on account of the low resistivity values of the fractured basement compared to the basement rock, all other aquifer formations at the other VES points (except for the irregular ones mentioned earlier) were identified as confined. This is because of the higher resistivity values of those formations compared to the basement rock.

Table 2 shows four classes of aquifer proactive capacity as delineated, to be high, moderate, weak and poor. While the aquifer at VES 20 was highly protected, twenty other aquifers were moderately protected. These were the aquifers at VES 1, 2, 22 - 33, 36, 37 , 38, 41, 42 and 44. Eight other aquifers had weak protection; these include the aquifers at VES points 3, 9, 13, 18, 21, 34, 40 and 41 . The remaining fifteen aquifers were poorly protected. They include the aquifers at VES points $4-8,10-12,14-17,19,35$ and 43 .

Generally, the aquifers are of good thicknesses and at reasonable depths, making them good reservoirs of water in appreciable quantity. However, most areas have high values of Transverse resistance which are associated with the zones of high transmissivity; hence, these zones are suggested for the installation of monitoring wells for the unconfined aquifer.

Table 2. Aquifer Parameters

\begin{tabular}{|c|c|c|c|c|c|}
\hline $\begin{array}{l}\text { VES } \\
\text { Point }\end{array}$ & Coordinates & $\begin{array}{l}\text { Aquifer } \\
\text { Thickness } \\
\text { (m) }\end{array}$ & $\begin{array}{l}\text { Depth.to } \\
\text { Aquifer (m) }\end{array}$ & $\begin{array}{l}\text { Long. Conductance.of } \\
\text { Overburden }\end{array}$ & $\begin{array}{l}\text { Aquifer Protective } \\
\text { Capacity }\end{array}$ \\
\hline 1 & $\begin{array}{l}09^{\circ} 02.794 \mathrm{~N} \\
006^{\circ} 34.137 \mathrm{E}\end{array}$ & 128.5 & 136.4 & 0.50462 & Moderate \\
\hline 2 & $\begin{array}{l}09^{\circ} 02.798 \mathrm{~N} \\
006^{\circ} 34.140 \mathrm{E}\end{array}$ & 86.95 & 87.92 & 0.0430554 & Moderate \\
\hline 3 & $\begin{array}{l}09^{\circ} 02.780 \mathrm{~N} \\
006^{\circ} 34.150 \mathrm{E}\end{array}$ & 107.2 & 107.8 & 0.1311378 & Weak \\
\hline 4 & $\begin{array}{l}09^{\circ} 02.782 \mathrm{~N} \\
006^{\circ} 34.108 \mathrm{E}\end{array}$ & 66.98 & 68.85 & 0.0120772 & Poor \\
\hline 5 & $\begin{array}{l}09^{\circ} 02.536 \mathrm{~N} \\
006^{\circ} 33.887 \mathrm{E}\end{array}$ & 58.29 & 59.50 & 0.0566047 & Poor \\
\hline 6 & $\begin{array}{l}09^{\circ} 02.533 \mathrm{~N} \\
006^{\circ} 33.878 \mathrm{E}\end{array}$ & 29.65 & 30.58 & 0.0659271 & Poor \\
\hline 7 & $\begin{array}{l}09^{\circ} 02.780 \mathrm{~N} \\
006^{\circ} 34.150 \mathrm{E}\end{array}$ & 65.91 & 66.66 & 0.0389932 & Poor \\
\hline 8 & $\begin{array}{l}09^{\circ} 02.529 \mathrm{~N} \\
006^{\circ} 33.863 \mathrm{E}\end{array}$ & 75.21 & 76.33 & 0.0112978 & Poor \\
\hline 9 & $\begin{array}{l}09^{\circ} 02.168 \mathrm{~N} \\
006^{\circ} 34.225 \mathrm{E}\end{array}$ & 63.89 & 69.74 & 0.1622901 & Weak \\
\hline 10 & $\begin{array}{l}09^{\circ} 02.140 \mathrm{~N} \\
006^{\circ} 34.241 \mathrm{E}\end{array}$ & 47.44 & 48.29 & 0.0580647 & Poor \\
\hline 11 & $\begin{array}{l}09^{\circ} 02.159 \mathrm{~N} \\
006^{\circ} 34.213 \mathrm{E}\end{array}$ & 93.00 & 95.24 & 0.0765885 & Poor \\
\hline 12 & $\begin{array}{l}09^{\circ} 02.168 \mathrm{~N} \\
006^{\circ} 34.225 \mathrm{E}\end{array}$ & 106.2 & 108.4 & 0.0206797 & Poor \\
\hline 13 & $\begin{array}{l}09^{\circ} 02.442 \mathrm{~N} \\
006^{\circ} 34.479 \mathrm{E}\end{array}$ & 86.36 & 87.49 & 0.104293 & Weak \\
\hline 14 & $\begin{array}{l}09^{\circ} 02.456 \mathrm{~N} \\
006^{\circ} 34.476 \mathrm{E}\end{array}$ & 45.39 & 49.39 & 0.04887 & Poor \\
\hline 15 & $\begin{array}{l}09^{\circ} 02.455 \mathrm{~N} ; \\
006^{\circ} 34.459 \mathrm{E}\end{array}$ & 89.42 & 91.31 & 0.05491 & Poor \\
\hline 16 & $\begin{array}{l}09^{\circ} 02.424 \mathrm{~N} \\
006^{\circ} 34.425 \mathrm{E}\end{array}$ & 5.32 & 83.65 & 0.0720332 & Poor \\
\hline 17 & $\begin{array}{l}09^{\circ} 02.719 \mathrm{~N} \\
006^{\circ} 34.426 \mathrm{E}\end{array}$ & 73.07 & 74.39 & 0.068164 & Poor \\
\hline 18 & $\begin{array}{l}09^{\circ} 02.714 \mathrm{~N} \\
006^{\circ} 34.456 \mathrm{E}\end{array}$ & 39.74 & 41.11 & 0.1109736 & Weak \\
\hline
\end{tabular}




\begin{tabular}{|c|c|c|c|c|c|}
\hline $\begin{array}{l}\text { VES } \\
\text { Point }\end{array}$ & Coordinates & $\begin{array}{l}\text { Aquifer } \\
\text { Thickness } \\
\text { (m) }\end{array}$ & $\begin{array}{l}\text { Depth.to } \\
\text { Aquifer (m) }\end{array}$ & $\begin{array}{l}\text { Long. Conductance.of } \\
\text { Overburden }\end{array}$ & $\begin{array}{l}\text { Aquifer Protective } \\
\text { Capacity }\end{array}$ \\
\hline 19 & $\begin{array}{l}09^{\circ} 02.724 \mathrm{~N} ; \\
006^{\circ} 34.462 \mathrm{E}\end{array}$ & 90.47 & 93.01 & 0.0899 & Poor \\
\hline 20 & $\begin{array}{l}09^{\circ} 02.728 \mathrm{~N} \\
006^{\circ} 34.471 \mathrm{E}\end{array}$ & 59.27 & 62.47 & 3.115 .437 & High \\
\hline 21 & $9.07216^{0} \mathrm{~N} ; 6.57080^{\circ} \mathrm{E}$ & 36.8 & 46.3 & 0.17847 & Weak \\
\hline 22 & $9.06780^{\circ} \mathrm{N} ; 6.56831^{0} \mathrm{E}$ & 22.6 & 34.4 & 0.20173 & Moderate \\
\hline 23 & $9.06760^{\circ} \mathrm{N} ; 6.57211^{\circ} \mathrm{E}$ & 17.8 & 23.0 & 0.20868 & Moderate \\
\hline 24 & $9.06700^{\circ} \mathrm{N} ; 6.57249^{\circ} \mathrm{E}$ & 12.7 & 20.4 & 0.29259 & Moderate \\
\hline 25 & $9.06374^{\circ} \mathrm{N} ; 6.57409^{\circ} \mathrm{E}$ & 36.1 & 55.0 & 0.37503 & Moderate \\
\hline 26 & $9.06467^{\circ} \mathrm{N} ; 6.57025^{\circ} \mathrm{E}$ & 25.1 & 41.4 & 0.34462 & Moderate \\
\hline 27 & $09.0719 \mathrm{~N} ; 006.5344 \mathrm{E}$ & 22.20 & 29.30 & 0.3775643 & Moderate \\
\hline 28 & 09.7619N; 006.554E & 22.30 & 29.10 & 0.3852721 & Moderate \\
\hline 29 & $09.7535 \mathrm{~N} ; 006.5532 \mathrm{E}$ & 41.45 & 50.65 & 0.36171 & Moderate \\
\hline 30 & $\begin{array}{l}09^{\circ} 02^{\prime} 57.3 \mathrm{~N} \\
006^{\circ} 35^{\prime} 59.9 \mathrm{E}\end{array}$ & 40.0 & 92.1 & 0.262963 & Moderate \\
\hline 31 & $\begin{array}{l}09^{\circ} 02^{\prime} 55.6 \mathrm{~N} \\
006^{\circ} 35^{\prime} 56.3 \mathrm{E}\end{array}$ & 10.0 & 16.4 & 0.207299 & Moderate \\
\hline 32 & $\begin{array}{l}09^{\circ} 02^{\prime} 53.6 \mathrm{~N} \\
006^{\circ} 35^{\prime} 52.9 \mathrm{E}\end{array}$ & 30.0 & 37.59 & 0.247916 & Moderate \\
\hline 33 & $\begin{array}{l}09^{\circ} 02^{\prime} 54.4 \mathrm{~N} \\
006^{\circ} 36^{\prime} 01.2 \mathrm{E}\end{array}$ & 2.45 & 4.92 & 0.216024 & Moderate \\
\hline 34 & $\begin{array}{l}09^{\circ} 02^{\prime} 43.7 \mathrm{~N} \\
006^{\circ} 36^{\prime} 01.6 \mathrm{E}\end{array}$ & 60.0 & 69.3 & 0.168349 & Weak \\
\hline 35 & $\begin{array}{l}09^{\circ} 02^{\prime} 50.5 \mathrm{~N} \\
006^{\circ} 35^{\prime} 53.6 \mathrm{E}\end{array}$ & 10.0 & 10.8 & 0.070985 & Poor \\
\hline 36 & $\begin{array}{l}09^{\circ} 02^{\prime} 59.8 \mathrm{~N} \\
006^{\circ} 36^{\prime} 04.6 \mathrm{E}\end{array}$ & 46.0 & 51.3 & 0.246562 & Moderate \\
\hline 37 & $\begin{array}{l}09^{\circ} 02^{\prime} 47.3 \mathrm{~N} \\
006^{\circ} 35^{\prime} 59.1 \mathrm{E}\end{array}$ & 54.0 & 55.6 & 0.213345 & Moderate \\
\hline 38 & $\begin{array}{l}09^{\circ} 02^{\prime} 45.4 \mathrm{~N} \\
006^{\circ} 35^{\prime} 54.2 \mathrm{E}\end{array}$ & 54.0 & 58.6 & 0.302182 & Moderate \\
\hline 39 & $\begin{array}{l}09^{\circ} 02^{\prime} 48.3 \mathrm{~N} \\
006^{\circ} 36^{\prime} 3.8 \mathrm{E}\end{array}$ & 54.0 & 54.6 & 0.167046 & Weak \\
\hline 40 & $\begin{array}{c}09^{\circ} 02^{\prime} 47.3 \mathrm{~N} \\
006^{\circ} 35^{\prime} 59.1 \mathrm{E}\end{array}$ & 26.0 & 28.2 & 0.12916 & Weak \\
\hline 41 & $\begin{array}{l}09^{\circ} 02^{\prime} 45.4 \mathrm{~N} ; \\
006^{\circ} 35^{\prime} 54.2 \mathrm{E}\end{array}$ & 20.0 & 22.2 & 0.213615 & Moderate \\
\hline 42 & $\begin{array}{l}09^{\circ} 02^{\prime} 45.4 \mathrm{~N} \\
006^{\circ} 36^{\prime} 05.3 \mathrm{E}\end{array}$ & 20.0 & 71.2 & 0.256361 & Moderate \\
\hline 43 & $\begin{array}{l}09^{\circ} 02^{\prime} 43.7 \mathrm{~N} \\
006^{\circ} 36^{\prime} 01.6 \mathrm{E}\end{array}$ & 6.00 & 8.39 & 0.098376 & Poor \\
\hline \multirow[t]{4}{*}{44} & $\begin{array}{r}09^{\circ} 02^{\prime} 42.2 \mathrm{~N} \\
006^{\circ} 35^{\prime} 57.8 \mathrm{E}\end{array}$ & 40.0 & 44.5 & 0.378279 & Moderate \\
\hline & Minimum & 2.45 & 4.92 & & \\
\hline & Maximum & 128.5 & 136.4 & & \\
\hline & Average & 48.36 & 56.68 & & \\
\hline
\end{tabular}

The highest and lowest aquifer thicknesses were observed at VES 1 and VES 33 with respective values of $128.5 \mathrm{~m}$ and $2.45 \mathrm{~m}$. The depth to the top of each aquifer varied from $4.92 \mathrm{~m}$ at VES 33 to $136.4 \mathrm{~m}$ at VES point 1 . The average aquifer thickness within the study area is estimated to be $48.36 \mathrm{~m}$ while the average depth to aquifers is estimated to be $56.68 \mathrm{~m}$. Boreholes drilled within the vicinity of the study area have had very good yield at depths ranging from $40 \mathrm{~m}$ to $60 \mathrm{~m}$. These results are consistent with those obtained by Tsepav et al., (2015) and Oladipo et al., (2011).

\section{Conclusion}

The geophysical survey has allowed us to obtain lithological identification and to characterize the conditions of the underground water of the studied area. Four geoelectric layers were identified; the top lateritic soil, sandy clay, fractured basement and the fresh 
basement. Aquifers thicknesses and depths to geoelectric layers were delineated within the study area. Areas with high values of Transverse resistance were associated with the zones of high transmissivity; hence, these zones are suggested for the installation of monitoring wells. The longitudinal conductance illustrates the non-permeability of the confining clay layer. Values of $\mathrm{S}>1.0$ siemens indicated zones in which the confined aquifer would be well protected; in comparison, values of $\mathrm{S}<1.0$ siemens would indicate zones of probable risks of contamination. Between these extreme values, moderately, weakly and poorly protected areas were also identified.

In order to fully harness the natural potentials of potable groundwater and its full utilisation, the following recommendations are evident:

i) Geophysical survey should be conducted anywhere there is need for potable groundwater to determine the best and most protected aquifers.

ii) Citing of indiscriminate dumpsites should be discouraged especially in the vicinity of residential houses so as to guide against the risk of exposure to contaminated groundwater.

iii) Geochemical analysis should also be conducted to ascertain the types of contaminant effluents present in the groundwater reservoirs, for the purpose of comparison to world standards.

iv) Where necessary, water from the suspected areas of contamination should be subjected to proper treatment before usage, especially for drinking.

v) Periodic geophysical and geochemical investigations should be undertaken to determine the rate of leachate migration in the areas so as serve as a guide for further groundwater developmental plans.

\section{Acknowledgement}

This work is part the Institutional Based Research (IBR) Grant project titled "Use of Geophysical Methods and Mathematical Models to Appraise Effect of Population Growth on Groundwater Systems of Lapai Town" sponsored by Tertiary Education Trust Fund (Tetfund), Abuja, Nigeria.

\section{Declaration of interests}

The authors declare that no known competing interests, whatsoever, that could have appeared to influence the work reported in this paper exist.

\section{References}

Ambade B, Sethi SS, Kumar A, Sankar TK. Health risk assessment, composition and distribution of polycyclic aromatic hydrocarbons (PAHs) in drinking water of southern Jharkhand, East India. Arch Environ Contam Toxicol, 2021, 80, 120 133. https://doi.org/10.1007/s00244-020-00779-y

Anonymous, Lapai. https://en.wikipedia.org/wiki/Lapai. Retrieved on $66^{\text {th }}$ August 2020.

Ayolabi, E.A., Adeoti, L., Oshinlaja, N.A., Adeosuni, I.O., and Idowu, O.I. Seismic Refraction and Resistivity Studies of part of Igbogbo Township, Southwest Nigeria: Journal of Science Research Development, 2009, 11, 42-61. Balkan. 
Bello, R; Balogun, AO; Nwosu, UM. Evaluation of Dar Zarrouk Parameters of Parts of Federal University of Petroleum Resources, Effurun, Nigeria Journal of Applied Science and Environmental Management. 2019, 23 (9), 1709-1715. Available at https://www.ajol.info/index.php/jasem

Environmental Protection Agency (EPA). What are the trends in the extent and condition of groundwater and their effects on human health and the environment? EPA's Report on the Environment (ROE), 2018, US EPA.

Idehen, O. A Comparative Investigation of Groundwater Contamination in Typical Dumpsites and Cemetery Using Ert and Physicochemical Analysis of Water in Benin Metropolis, Nigeria. Journal of Geoscience and Environment Protection, 2020, 8, 72-85. doi: 10.4236/gep.2020.81005.

Li, P., Karunanidhi, D., Subramani, T. Sources and Consequences of Groundwater Contamination. Arch Environ Contam Toxicol, 2021, 80, 1-10. https://doi.org/10.1007/s00244-020-00805-z

Muhammad Salik Javaid, Laila Khalid and Muhammad Zeshan Khalid. Analytical Study of Environmental Impacts and Their Effects on Groundwater Hydrology, Groundwater Hydrology, Muhammad Salik Javaid, IntechOpen, 2020, DOI: 10.5772/intechopen.88002: https:/www.intechopen.com/books/groundwaterhydrology/analytical-study-of-environmental-impacts-and-their-effects-ongroundwater-hydrology

Obaje N.G., Goki N. G., U. M. Umar, A. K. Aweda, T. M. Ozoji, A. Nandom. Mapping and Characterization of Some Industrial Mineral Deposits in North-Central Nigeria as Raw Materials for Industrialization International Journal of Sciences: Basic and Applied Research (IJSBAR), 2019, 48, (1), 160-182.

Obaje Nuhu George, Abdullahi Bomai, Sunday Dabai Moses, Mohammed Ali, Abdulwahid Aweda, Serah Japhet Habu, Abdullahi Idris-Nda, Aliyu Isah Goro, Salome Waziri, Updates on the Geology and Potential Petroleum System of the Bida Basin in Central Nigeria, Petroleum Science and Engineering, 2020, 4(1), 23-33. doi: 10.11648/j.pse.20200401.13

Obiora Daniel N, Adeolu E Ajala and Johnson C Ibuot. Evaluation of aquifer protective capacity of overburden unit and soil corrosivity in Makurdi, Benue state, Nigeria, using electrical resistivity method. Journal of Earth Systems Science, $2015,124,1,125-135$

Olabode T.O, Eduvie, M. O. and Olaniyan, I. O. Evaluation groundwater resources of the Middle Niger (Bida). Researcher, 2012, 4(7), 1 - 6.

Oladipo, M. O. A, Njinga, R. L, Baba, A and Mohammed, I. Contaminant Evaluation of Major Drinking water sources (Boreholes) in Lapai Metropolis, Advances in Advanced Science Research, 2011, 2(6):, 123 - 130.

Olajide A., Bayode S., Fagbemigun T., Oyebamiji A., Amosun J. and Owasanoye A. Evaluation of Aquifer Protective Capacity and Groundwater Potential in Part of Iju, Akure-North, Ondo State, Nigeria. Journal of Nigerian Society of Physical Sciences, 2020, 2, 197-204

Ololade, I.A., Arogunrerin, I.A., Oladoja, N.A. . Concentrations and Toxic Equivalency of Polycyclic Aromatic Hydrocarbons (PAHs) and Polychlorinated Biphenyl 
(PCB) Congeners in Groundwater Around Waste Dumpsites in South-West Nigeria. Arch Environ Contam Toxicol., 2021, 80, 134-143. https://doi.org/10.1007/s00244-020-00790-3

Olorunfemi, M. O., Ojo, J. S. and Akintunde, O.M. Hydro-geophysical evaluation of the groundwater potential of the Akure metropolis, Southwestern Nigeria. Journal of Mining and Geology, 1999, 35(2), $207-228$.

Oni, A.G., Eniola, P.J., Olorunfemi, M.O. Okunubi M. O. and Osotuyi G A. The magnetic method as a tool in groundwater investigation in a basement complex terrain: Modomo Southwest Nigeria as a case study .Appl Water Sci 2020, 10, 190. https://doi.org/10.1007/s13201-020-01279-z

Osuagwu, B.C. Geophysical investigation for groundwater in a difficult terrain around Modomo Area, Ife, Osun State: Unpublished Bachelor of Science Thesis, Obafemi Awolowo University, Ile-Ife, Osun State, 2009, 88.

Rahaman, M. A. O., S.L. Fadiya, S.A. Adekola, S.J. Coker, R.B. Bale, O.A. Olawoki, I.J. Omada , N.G. Obaje, O.T. Akinsanpe, G.A. Ojo, W.G. Akande. A revised stratigraphy of the Bida Basin, Nigeria. Journal of African Earth Sciences, 2019, 151, 67-81

Tsepav M. T and Isreal M. O. Preliminary investigation of some areas of Ibrahim Badamasi Babangida University, Lapai, using D. C resistivity method. Journal of Basic Physical Research 2011, 2(1), , pp57 - 65.

Tsepav M.T, Ibrahim S.I and Bayegun F.A. Geoelectrical Characterization of Aquifer Precincts in Parts of Lapai, North Central Nigeria. Journal of Applied Sciences and Environmental Management. 2015, 19 (2), 295 - 301. 